\title{
Periosseous Route of Administration
}

National Cancer Institute

\section{Source}

National Cancer Institute. Periosseous Route of Administration. NCI Thesaurus. Code C149753.

Administration of a medicinal product on or around the bone 